\title{
CIVIC AND CONFESSIONAL MEMORY IN CONFLICT. AUGSBURG IN THE SIXTEENTH CENTURY
}

\author{
Sean F. Dunwoody
}

In the summer of 1584 , an uprising over a reform of the calendar in the city of Augsburg occasioned a struggle to define both the memory of the debates that had precipitated the uprising and the memory of what the uprising was about. In Augsburg, the magistracy adopted the reformed Gregorian calendar against the will of an increasingly organised oppositional Protestant group formed around the Protestant ministers, the municipal church warden, and members of the municipal elite. In debates and legal suits prior to the adoption of the reformed calendar and in the aftermath of the introduction of the reform, the two sides pursued divergent strategies of framing the events. On the one side, the magistracy cultivated a memory of the debates and of the uprising as one of politico-legal authority challenged; and it sought to demonstrate its authority over public spaces within the city and its authority as an imperial estate within the structures of the Holy Roman Empire. On the other side, the oppositional Protestant group cultivated a memory of the events within the frame of the soteriological story of Christian persecution, martyrdom, and constancy.

Such divergent strategies of cultivating memory are not surprising in an age of confessionalizing cultures. What is remarkable, however, is the fact that these divergent strategies were cultivated within a single community, and centring on an event that nearly upended all civil life, and yet did not lead to further conflicts. On the contrary, the two memories coexisted within a community that managed to keep the peace even in an age of growing confessional-political tensions in the wider Empire. What is surprising about Augsburg is thus not only the degree to which this community showed itself capable of generating divergent memories of a contentious moment in the city's history, but the degree to which Augsburg's citizens were capable of accommodating them.

How was it possible for some Augsburgers to cultivate a memory centred around their identity as members of a persecuted faith groaning 
under the tyranny of magisterial authority, while simultaneously embracing their place within the civic elite of the city? Though this essay cannot answer this question fully, it can help us better appreciate the degree to which the Reformation gave rise to a new world in which particularistic, confessionalised memories and identities could be crafted that were at odds with municipal or official memories and identities. The way in which these two memories were simultaneously accommodated in Augsburg reveals something of the ways in which this city, unlike so many similar communities in early modern Europe, remained largely at peace in the face of confessional diversity. ${ }^{1}$ In this essay, I will explore the divergent strategies used to construct competing memories of the events surrounding the introduction of the Gregorian calendar in Augsburg and suggest how these strategies underlined divergent conceptualisations of community in the wake of the Reformation. I argue that divergent memories were grounded on divergent foundations: the accusatory writings of the oppositional Protestant group, especially in the person of Augsburg's former superintendent of the Protestant churches in Augsburg, Georg Müller, were rooted in their claims to probity as preachers of the Word, as exemplified in their use of biblical references drawing parallels with the present. By contrast, the exculpatory publications of the council highlighted juridical procedures rooted in imperial traditions and constitutional prerogative in order to emphasise the legality of its actions. As such, these two justifications underline the degree to which political and confessional unity could be split in the wake of the Reformation.

Similarly, each side sought to articulate the space of its memory in its own particular way. Müller and his party crafted their narrative clandestinely in the city, through missives sent by an exiled minister to his congregants left behind in Augsburg. The magistracy, through its main spokesman, the city syndic Georg Tradel, ${ }^{2}$ asserted its power to craft the official memory of events by proclaiming its narrative in the council house and in the public squares of the city. Each side mobilised publishing networks that underlined confessional allegiance, on the one hand, and traditional municipal authority, on the other.

A religiously pluralist imperial city is an especially useful context in which to think about this development for several reasons. First, in the

\footnotetext{
1 I explore this process of peace more fully in my dissertation, 'Conflict, confession, and peaceful coexistence', PhD diss., University of Chicago (2012).

2 Gernot Ludwig, 'Dr. Georg Tradel, ein evangelischer Jurist aus Dillingen', Jahrbuch des Historischen Vereins Dillingen an der Donau 90 (1988), 326-340.
} 
absence of princely superioritas, imperial cities are arguably the most extreme case of fractured authority in the early modern world. The radical diversity of early modern authority structures could be read on the cityscape of any early modern imperial city, and this was most certainly the case in Augsburg. Second, the religiously pluralist society of a city like Augsburg forced explicit, critical re-examination of the foundations of the commonwealth in a way that was usually only latent in pre-Reformation imperial cities or in cities where only one faith was legally sanctioned and tolerated. In some parts of contemporary Europe, religious conflict, once overcome, was supposed to be 'forgotten' and painful memories of the past cast into oblivion. ${ }^{3}$ On the other hand, in confessionally uniform Protestant cities and principalities, confessional identity prompted historically minded authors to rewrite memories of the past and of recent tribulations as trials of the righteous at the culmination of history. 4

In a city like Augsburg, however, neither of these things was entirely possible. As we shall see, magisterial attempts to impose a 'forgetting' of injuries suffered proved unsuccessful. At the same time, confessional pluralism prevented the emergence of an officially sanctioned confessionalised memory of the events. In the place of these two alternatives-far more familiar to scholars of religious conflicts in early modern Europe-stood a third: a reconsideration of the place and limits of political authority and civic life, on the one hand, and of religion and confessional particularism, on the other. Competing memories in Augsburg of the Calendar Controversy and of the events of 4 June 1584 and the way in which this particular 'memory war' was resolved offer insights into Augsburg's peculiar success at maintaining religious peace in an age of religious war.

That the traditional Julian calendar was in need of correction was not the discovery of Europeans in the Age of the Reformation. For centuries, scholars had sought to offer a way of realigning the civil calendar with the astronomical realities, an incongruity that had led to calendrical Easter

3 See, for instance, Philip Benedict, 'Divided memories? Historical calendars, commemorative processions and the recollection of the Wars of Religion during the Ancien Regime,' French History 22 (2008), 381-405.

4 D.M. Loades (ed.), John Foxe and the English Reformation, St. Andrews studies in Reformation history (Aldershot and Brookfield, VT: Scolar Press, 1997); Gregory B. Lyon, 'Baudouin, Flavius, and the plan for the Magdeburg Centuries', Journal of the History of Ideas 64, no. 2 (2003), 253-272. 
slipping ever further back into astronomical winter. ${ }^{5}$ By 1582, the calendric vernal equinox fell on 11 March, ten days earlier than the astronomical equinox. The solution-one that was ultimately sanctioned by the Catholic Church-called for skipping ten days on the calendar. Accordingly, on 24 February 1582, Pope Gregory XIII decreed the implementation of the reform in the night of $4-5$ October 1582 (so that the next day was reckoned as 15 October). The papal bull in which the decree was included, Inter gravissimas, threatened excommunication as the penalty for all who failed to institute the reform. At first, the new calendar was implemented only in the Papal States; but the Papacy invested considerable efforts in seeing that it was adopted everywhere.

Recognition of the calendar's inaccuracies was ecumenical, but because the change was ordered by the pope, to many Protestants throughout Europe, the new calendar came to be considered anathema. Adoption might insinuate papal authority in Protestant territories; it could imply papal authority over civil and their derivative liturgical calendars. In a short time, this inchoate sentiment had started to evolve into a unified, theological opposition.

The city of Augsburg was in a particularly difficult position. Inhabited by both Protestants and Catholics and surrounded by Catholic powers already committed to the new calendar, the Augsburg magistracy necessarily had to apply a more complicated calculus. Some of Augsburg's Protestants feared that the calendar reform might be a first step towards a papal take-over of the city; petitions were sent to the city council by the

5 On the history of the calendar, the recognition of its defects, and of efforts to reform it, see Gregorian reform of the calendar. Proceedings of the Vatican Conference to commemorate its 4ooth anniversary, 1582-1982, ed. George V. Coyne, Michael A. Hoskin, and Olaf Pedersen (Vatican City: Pontifica Academia Scientiarum, Specola Vaticana, 1983). For a more specific review of the situation in Germany, see Felix Stieve, 'Der Kalenderstreit des 16. Jahrhunderts in Deutschland', Abhandlungen der historischen Classe des königlich Bayerischen Akademie der Wissenschaften 15, no. 3 (1880), 1-99. See also Dirk Steinmetz, Die Gregorianische Kalenderreform von 1582. Korrektur der christlichen Zeitrechnung in der frühen Neuzeit (Oftersheim: Steinmetz, 2011), esp. 46-72. The following survey of events is indebted to Paul Warmbrunn, Zwei Konfessionen in einer Stadt. Das Zusammenleben von Katholiken und Protestanten in den paritätischen Reichsstädten Augsburg, Biberach, Ravensburg und Dinkelsbühl von 1548 bis 1648 (Wiesbaden: F. Steiner, 1983), esp. 359-375; Eberhard Naujoks, 'Vorstufen der Parität in der Verfassungsgeschichte der schwäbischen Städte (1555-1648). Das Beispiel Augsburg', in Jürgen Sydow (ed.), Bürgerschaft und Kirche (Sigmaringen: Thorbecke, 1980), 38-66; and especially Bernd Roeck, Eine Stadt in Krieg und Frieden. Studien zur Geschichte der Reichsstadt Augsburg zwischen Kalenderstreit und Parität, 2 vols. (Göttingen: Vandenhoeck \& Ruprecht, 1989), vol. 1, esp. 125-137. 
Protestant church wardens voicing their opposition. ${ }^{6}$ They even submitted a petition to the Imperial Chamber Court to force the council to stay any decision. By contrast, the majority of the politically active citizenrythe confessionally mixed patriciate and the largely Protestant merchant elite-focused on Augsburg's economic fate, fearing the consequences were the city to be left ten days behind its neighbouring territories. ${ }^{7}$ Both quotidian provisioning of the city and the annual trading cycles of the longdistance merchants would be subject to considerable inconveniences. ${ }^{8}$ In the end, the council_-Protestants and Catholics alike-decided to implement the new calendar against the protests of Protestant theologians in other territories, initially only in 'court, council, and market days' to satisfy a stay issued by the Chamber Court. ${ }^{9}$ Though the council had won support from a (mostly Protestant) Diet of Cities in 1583, it soon faced an oppositional group in Augsburg that railed against the new calendar. This group - which grew and coalesced around the lay Protestant church wardens, the ministers, and especially Georg Müller-not only voiced their opposition from the pulpit but also continued their case before the Chamber Court. Meanwhile, within the city, each side disputed the legitimacy of the other's claim to speak with authority in the matter. ${ }^{10}$ What had begun as a relatively unexciting question of ensuring the relative correspondence of civil and church calendars with astronomical realities had

6 Stadtarchiv Augsburg (hereafter: StadtAA), Reichsstadt (hereafter: RS), Rat, Ratsprotokolle, ad 1583 January 15 , f. 5 r.

7 For a reading that emphasises the confessional aspect of the conflict from the perspective of a key contemporary's correspondence, see Regina Dauser, Informationskultur und Beziehungswissen. Das Korrespondenznetz Hans Fuggers (1531-1598) (Tübingen: Niemeyer, 2008), 251-283.

8 Dauser, Informationskultur, 258, though Dauser implies that the council's decision was driven far more by confessional considerations than mercantile ones. In this, she follows the interpretation of Warmbrunn, Zwei Konfessionen. By contrast, Roeck's interpretation centres on commerce: Eine Stadt, vol. 1, 125. Roeck's arguments, taken together with Naujoks' foregrounding of confessional and economic grievances ('Vorstufen'), can be taken as an indication of the complexity of the events beyond a simply confessional mindset.

9 StadtAA, Rat, Ratsprotokolle, ad 1583 January 5 , f. 3 r. See also the council justification in ibid., ad 1583 January 19, ff. $7 \mathrm{r}-8 \mathrm{r}$. See also StadtAA, RS, Geheimer Rat, Religionsakten, Serie B, Kalenderstreitsakten, vol. 6o, f. 16v; Tradel claims that two sitting mayors, Ulrich Walther, a Protestant patrician, and Andreas Harder, a Protestant merchant, approved the measure. Council decision regarding civil matters: see the council decision of 29 March 1583, StadtAA, RS, Rat, Ratsprotokolle, f. $24 \mathrm{~V}$.

10 See for instance the exchange between the theologians and jurists reproduced in Staats- und Stadtbibliothek Augsburg (hereafter: SStBibAugsburg), $2^{\circ} \operatorname{cod} \mathrm{H} 18$, 'Augspurgischer Calender-Streit von anno 83 bis 9o', ff. 52-68 and 69-92, respectively. 
become a question crucial to both the Protestant community in Augsburg and the civil magistrates.

In the following months, tensions between the two sides only grew. Both political authorities and religious authorities - and their respective supporters in the wider populace-perceived the other to be encroaching on their rights and authority. Though the council tried to maintain the distinction between enforcing the calendar reform in civil matters and allowing the Protestant churches to retain the old calendar in their liturgy, peace was not achieved in the community. The divergence between the two calendars created considerable problems in everyday life. For instance, the overwhelmingly Protestant butchers refused to slaughter their cattle at the end of Lent in 1584; according to their calendar, the traditional Lenten prohibition on eating meat had not yet been lifted. ${ }^{11}$ However, for the council a line was crossed when the leader of the Protestant activist front in Augsburg, Georg Müller, authored a text in support of the Protestants in Cologne. In the text, Müller claimed that a citizenry had the right to overthrow a council. ${ }^{12}$ The obvious implications for Augsburg were too dangerous to ignore. When the same Müller led his fellow ministers in a defiant public rejection of a new council order in May 1584 ordering the reform of the Protestant liturgical calendars, the council decided to take more drastic measures.

On 4 June 1584, the council attempted to quietly seize Müller from his home and banish him from the city. The plot was discovered and the reaction swift. Within hours an armed mob of several thousand had gathered in the city centre around the council house, where panicked authorities trapped inside feared an overthrow of the government. We should see in this mob of artisans not only an angry reaction to a single event but an expression of discontent about the loss of political standing by guildsmen since the 1540 . The decision to focus energies on the prominently public space of the council house and the square before it was therefore no coincidence.

In the end, the mob refrained from open assault on the authorities, but they were quieted only by the arrival of the remaining Protestant ministers, who persuaded the populace to return to their homes. Though spectacular, the event resulted in little real violence. However, the clearing of

11 StadtAA, RS, Rat, Ratsprotokolle, ad 1584 February 4, f. 7 v.

12 Georg Müller (Mylius), Christlicher Sendtbrieff an einen Ersamen Raht der... Reichßstadt Cölln... (Heidelberg, 1583). 
the council house square only signalled the shift of the struggle to new terrain: a new battle was already brewing over how to craft a memory of the events.

The council was the first to begin articulating its own version of events. From the start, the council's efforts at memory-making appealed to traditional understandings of political authority. On 14 June 1584, the council published a proclamation, issued throughout the city's marketplaces, in the city squares, and other key sites of public authority in the city. ${ }^{13}$ In doing so, the council reclaimed those civic spaces briefly claimed by the mob. As laid out in the council's proclamation, the uprising occurred on account of the lack of proper deference to the civic authorities, the failure to maintain civic fraternity and the privileging of particularistic, confessional identities at the expense of a shared municipal one. If plastering the city's public spaces with proclamations was done in support of the council's claim to political authority, the same concern for undivided political authority also figured prominently in the council's next move.

Two weeks after the uprising, once hotter heads had cooled somewhat and the council again felt itself in undisputed practical control of the city, the council pressured the preachers to issue a statement from their pulpits during their Sunday sermons. In this statement, the preachers were forced to voice their acceptance of the magistracy's version of the events and their causes. With only minor changes, the statement repeated the main claims of the council's first post-crisis proclamation. ${ }^{14}$ In forcing the ministers to read this proclamation from their pulpits before their congregations, the council sought to reassert the political subordination to civic authority of the ministers, who in the previous few years had preached in increasingly strident tones.

The third step in the council's crafting of its memory of the events was to ground them in an insistence upon the council's political and legal function within the frame of the Empire. Accordingly, the council commissioned the publication of several pamphlets that included large portions of the materials submitted to and issued by the Imperial Chamber Court, where the council's position was ultimately vindicated. ${ }^{15}$ Legal authority

13 'Berüff So ein E Raht der Statt Augspurg den 14. Junij Anno 1584. auff den Plätzen der Stat thün vnd publicieren lassen', in SStBibAugsburg, 4 Aug 1021, 'Ordnungen ...', vol. 1.

14 StadtAA, RS, Geheimer Rat, Religionsakten, vol. 58, ff. 85r-91r.

15 Publikation der Röm[ischen] Kai[serlichen] Maj[estät] zwischen der Oberkeit und den Kirchendienern Augsburgischer Konfession in der Stadt Augsburg ergangenen letzten Resolution, ([Augsburg], 1586). 
and the council's place within the traditional political structures of the Empire were used as a means of authenticating the narrative constructed by the council. These pamphlets did more than merely restate the council's legal and procedural justifications for an audience at home; it is clear that the council was now writing for a wider Imperial audience that was highly attuned to the events in Augsburg. These pamphlets also sought to undermine an emergent, confessionalised counter-narrative of the events. As a council pamphlet put it:

An honourable council knew that God the Almighty, the one true author, source, protector, and guardian of all lordly authority and just causes, would never abandon his ordered creation and right justice, but rather that he would in his own good time, against all improper abominations, ensure that truth shone through. To God is due the highest and most obedient thanks and praise, that he, in his grace, ensured that the council's righteousness shone through as brightly as the midday sun. ${ }^{16}$

At this point, the council appears sensitive to the fact that religious ideals stood at the heart of the conflict. Accordingly, the council claimed the standard of righteousness for itself. The divine order was invoked to underline the justice of the council's legal and jurisdictional claims. The Protestant activist front bore responsibility for the uprising and for the general distrust among the citizenry, according to this council portrayal, because it had failed to respect the council's divine authority and jurisdiction, and especially to acknowledge that this authority was imperially sanctioned and constitutionally prescribed.

This official effort to craft the memory of events did not go unchallenged for long. The same minister who had channelled the emergent confessionalised identity of Augsburg's Protestants from the city's pulpits, Georg Müller, now took up the pen to ensure that his former congregants' memory of the events was not determined by the council's position. Writing from his exile in Ulm, Müller offered a 'missive and letter of solace' (Send- und Trostbrief) as an immediate reply to the council's version of events. In his absence, Müller reminded Augsburgers of the righteousness of their religious purpose and counselled steadfastness in a time of troubles. The events of 4 June, and all that had happened since, were bound

16 Publication / dern in der Calender sach / am hochlöblichen Kayserlichen Camergericht zü Speyer / den 13. dem Alten / oder den 23. tag May dem Newen Calender nach / zurechnen / jetztlauffenden 1584. Jars / für einen E Raht der Statt Augspurg / vnd wider etliche desselben widerwertige / eröffneter Urteil, a copy of which can be found in Stadt- und Staatsbibliothek Augsburg, $4^{\circ}$ Aug 1021, Ordnungen ... vol. 1, document no. 2. 
up in an almost eschatological framework, all tied to his congregants' identity as steadfast Protestants. ${ }^{17}$

A version of this missive was soon published for an audience that Müller now understood to be interested in this oppositional Protestant memory of events. ${ }^{18}$ The meaning and memory of Augsburg's domestic dispute was now being fought out before the much larger audience of the Imperial political public. The themes that Müller employed in this pamphlet reflect an attempt to frame the events in Augsburg as a story of individual salvation in the context of iniquitous secular powers. Accordingly, Müller's story is framed around biblical analogies. Rather than searching for justification with references to legal rights and procedural measures taken in the Empire's various institutions, Müller looked to the story of Exodus. Here, in his portrayal, Augsburg's Protestants - that is, Augsburg's true Christians - suffer under the unjust rule of a magistracy that is obstinate against God, which will ultimately lead to its downfall:

And yet every day their hearts are emboldened to seize at the Lord their God, and just like Uzziah, the king of Judah, they usurp what does not belong to them but to the ministers, who have been consecrated. They do not do God honour by that. Rather, they will be punished and the Church shall remain in the good order meant for it by God. ${ }^{19}$

Müller's reference here is to the story in the Second Book of Chronicles, in which Uzziah, in his arrogance and immoderation, usurped the priestly right to burn incense for God. What Müller does not spell out, but references only obliquely, is the outcome of that biblical parable: Uzziah, in the moment of his usurpation, was struck by leprosy, forced to cede the reign to his son; he lived out his days in seclusion. For Müller's Augsburg audience, the moral of this story was unmistakable: whereas the council made every effort to justify itself with reference to a-confessional legal rights and super-confessional imperial institutions, Müller sees only Catholics on one side and Protestants on the other. For him, the council in

17 A Latin version of this letter, 'Dominis Georgij Mylij ex Ulm 29. Maij, ao: 84. Reuerendis \& doctis viris \& Dominis M: Martino Riegero \& alijs Ministris Augustam versus missae litterae' can be found in SStBibAugsburg, $2^{\circ}$ cod. Aug. 195, 'Acta Augustana d.i. Amtshandlungen und amtliche Correspondenz der Stadt Augsburg 1566-1745', vol. 2.

18 Send- und Trostbrief an die evangelische Bürgerschaft in Augsburg, da ihre Seelsorger zur Stadt ausgetrieben worden (Wittenberg: Matthäus Welack, 1586), included in Stadtund Staatsbibliothek Augsburg, $4^{\circ}$ Aug 1021, Ordnungen ... vol. 1 as document no. 5 .

19 Ibid. 
Augsburg - even though there were still many Protestants in high municipal offices-is only a 'Papist council'.

Later that year, Müller published a second, widely disseminated pamphlet with different themes, but an identical purpose. The events in Augsburg were an attempt at unjust usurpation of priestly authority on the part of the council; and the Augsburg Protestants' suffering was a reflection of the Gospel story of suffering and salvation. ${ }^{20}$ The Augsburgers' actions were not a question of legal subjecthood, but rather of moral responsibility and Christian duties. Müller then rather quickly moves from these abstract pastoral admonitions to an explicit framing of the Augsburg events of $1583-84$ as a story concerning Christian duty in a divinely ordained plan: the suffering in this life is a part of attaining the Kingdom of God. It is the true believers who suffer; they are the ones that are hated, who are insulted. In fact, their suffering at the hands of iniquitous rulers is a mark, a proof of their faith.

It is unsurprising that the council in Augsburg rejected this soteriologically centred memory of the events of $1583-84$. Instead, the council and Tradel restated and elaborated the official municipal memory of events as a matter of procedural, legal, and constitutional propriety on the part of the council, challenged by a cabal of disobedient citizens. In the document the council commissioned and published in response to Müller's publication, entitled 'Truthful Rejoinder to the Infamous Libel', the approach was markedly different. ${ }^{21}$ Here, the matter was one of civil discord. Müller had sought to rend the commonwealth in two and, to an extent, the authors concede, he succeeded. Inasmuch as his readers believed his fantastical version of events-Tradel calls Müller's text a 'fiction' (gedicht) - the effect has been of discord and divisions. There is no trust or friendship (vertrawen oder Freündschafft) between the council and Augsburgers. ${ }^{22}$

20 Georg Mylius, Augsburgische Handel, so sich wegen der Religion und im währenden Kalenderstreit mit Georgen Müller zugetragen (Wittenberg, 1586).

21 Der Herren Pfleger vnd Gehaimen Rät des heyligen Reichsstatt Augspurg Warhaffter gegenbericht / der Augspurgischen Händel vnd gegründte widertreybung und D. Georg Müllers nechstuerschinen 1586. Jars in Truckh außgetrewten Famos gedichts (Augsburg: Valentin Schönigk, 1587). A copy of this can be found in StadtAA, RS, EWA 510, vol. 2. On the printer Schönig(k): Theodor Wohnhaas, s.v. 'Die Schönig', Archiv für Geschichte des Buchwesens 5 (1964), col. 1473-1484; Schönig was, like most of Augsburg's printers, a Protestant. In 1572/73, he became the city's official printer (Stadtdrucker).

22 'Wann aber sein Famoßschrifft nit nun die Personen der Oberkeit priuatim verletzt / sondern sein gedicht zü gemeiner Statt allhie jmmerwerender zerrüttung vnnd spaltung / vnnd zu anrichtung newen vngehorsams vnnd mißtrawens wider die Oberkeit / one mittel gereichte... wa in gemein seinem gedicht / sonderlich bey diser Statt / geglaubt wurde / 
In discounting Müller's accusations, Tradel cultivates an official memory of the events that, in the course of fifty-three punctilious steps, relies on jurisdictional, legal, procedural and constitutional claims to counter Müller's version of the events.

The memory of the events leading up to the uprising of 4 June had clearly become a question of some considerable significance, quite obviously to the Augsburg magistracy. That Müller initially felt compelled to counter this official memory of events does not surprise, given his prominent position within the Augsburg Protestant community. But even years later, from the distance of his new life and professional commitments in Saxony, Müller remained committed to the cultivation of the oppositional Protestant memory of the events. Whether Müller continued to pursue the matter out of a residual sense of pastoral obligation to his Augsburg flock or whether he did so out of commitment to the Protestant cause in the increasingly acrimonious exchanges circulating in wider Imperial circles, Müller's crafting of the memory of events remained focused on the centrality of confessional identity. Like his first letter sent back to Augsburg in the early months of his exile in Ulm, this latest document, published in Wittenberg, adopted the voice of a concerned pastor for his congregants. In his Send- und Trostbrief an seine lieben Pfarrkinder in Augsburg ('Missive and Letter of Condolence to his Dear Pastoral Children in Augsburg'), Müller continued to attack the memory of events cultivated by Tradel and to which, in the meanwhile, most of the remaining ministers in Augsburg had acquiesced. ${ }^{23}$ Whereas Tradel and the council wanted to remember the events of $1583 / 84$ as centred around the a-confessional legality and constitutionality of the Empire's institutions, and Augsburg's own place in the Empire, Müller emphasised a memory centred on the Protestants in Augsburg as defined by their confessional affiliation. As Protestants, what befell them was an imitation of biblical precedents. However, in contrast to his earlier texts, Müller's own role was now amplified: Müller is now like David, who, in the Books of Samuel, after the death of Saul and David's ascension to the throne of Israel, was driven from Jerusalem by the Jebusites.

vnnd daselbst hero kein vertrawen oder Freündtschafft zwischen der Oberkeit / vnnd den Inwohnern derselben / vnmmermehr auffgepflantzt werden möchte ...; Der Herren Pfleger vnd Gehaimen Rät des heyligen Reichsstatt Augspurg Warhaffter gegenbericht.

${ }^{23}$ The pamphlet was published by Zacharias Krafft in Wittenberg (1586); see StadtAA, RS, EWA, No. 510, vol. 1. 
In accordance with his rejection of the political and legal frame of the official memory of the events, Müller could not see the council as magistrates, but rather as either Catholics or Protestants who happened to occupy an office in the magistracy. And because there were more Catholics than Protestants in the council in Augsburg in the 1580s, for Müller the magistracy is a Catholic magistracy. Müller recalled the events in Augsburg not as a matter of legal, constitutional or procedural dispute, but as an instantiation of confessional primacy, refracted through a biblical lens, which sees Augsburg's Protestants and now especially Müller himself as reiterations of the chosen people of the Bible. And because Tradel and those Protestant ministers in Augsburg who had accommodated themselves to council oversight and the calendar reform were likewise Protestants, they had to be revealed as false Christians. Noteworthy about Müller's continued efforts in cultivating a Protestant memory of the events in Augsburg is the degree to which his own movement from Augsburg to Ulm and later to Wittenberg parallels the way the crafting of a memory of the events of $1583 / 84$ had become as much an imperial as a local issue.

By this point, the memory of the events in Augsburg of $1583 / 84$ had developed along two divergent strands. On the one hand, there was an increasingly Empire-wide memory battle over whether the dispute in Augsburg was one of just civil authority and jurisdiction or confessional violence and depredation. This memory war was fought by the council on the one side and Müller on the other. Each enjoyed the growing support of imperial confessional networks of publishers and audiences keenly interested in the Augsburg affair. Just as the memory of Magdeburg or of the Bartholomew's Day massacre had become important chapters in the confessionalised memory of the Empire's Protestants, so too did the creation and maintenance of a certain interpretation of the 'Calendar Crisis' became a hallmark of imperial Protestant memory. The confessional steadfastness of men like Müller was celebrated as a model of Protestant conduct in Augsburg and in the Empire. Yet, while Protestants in confessionally uniform territories could openly celebrate their memory of the events in Augsburg in 1583/84, Protestants in Augsburg were foiled in similar efforts.

Just as the Augsburg council went to considerable lengths to refute Müller's missives both for a domestic and an imperial audience, it also set strict policies frustrating attempts by certain parts of Augsburg's Protestant community to live out a memory of the events of $1583 / 84$ as a religiously persecuted group. First, the council worked to prevent attempts to 
commemorate Müller. The council even charged the Protestant ministers with helping to reject any residual celebration of Müller in the citizenry, something that the ministers did, but to little effect. ${ }^{24}$ On the contrary, the ministers in Augsburg frequently complained of the abuse they suffered from their congregants. That is, those parts of the Protestant citizenry that identified with Müller were still able to implicitly challenge the council's version of the events as pertaining to constitutional or procedural matters. Though the council's authority could not easily be defied, the council's ministers - the so-called 'scabs' - could be boycotted. Ordinances forbidding baptisms outside the city or privately at home and those forbidding marriages elsewhere could not entirely prevent many of Augsburg's Protestants from seeing the events as a question of confessional identity. There was little that the council in Augsburg could do to stop this more passive form of resistance. However, the council was far more stringent in its enforcement of the use of the Gregorian calendar. Particularly in the years between 1586 and 1600 , it made considerable efforts to ensure that all artisans-including those in the more sensitive trades, like butchers-observed the calendar reforms in all of their dealings, whether it meant slaughtering cattle before Ash Wednesday or working on municipal construction projects during what, by the old calendar, was a Sunday. The municipal authorities used an extensive network of spies and informants to find out which weavers wove on a day that, by the new calendar, was a holiday. These people, so suspected the council, sought to live out in defiance of the municipal authorities their everyday lives in line with an interpretation of the events of 1584 as an episode of confessionalised martyrdom. ${ }^{25}$ Through such measures, the council in Augsburg sought to enforce public acceptance of its official memory of the troubles as a matter of legal and constitutional authority.

Nonetheless, since the judicial and occasional sources reveal a number of cases from the 1590 in which some of Augsburg's Protestant community continued to celebrate their feast days (and observe civil holidays) in accordance with the Julian Calendar, we can see that counter-memories of the events of the 1580 semained pervasive. In addition to observing the

24 One minister, Stephan Engelbronner, penned an appeal to the Protestant community in Augsburg, entitled 'Ein Kurze Aber Christliche vnd nottwendige / Vermahnung...', in StadtAA, RS, EWA, no. 511, doc. no. 46), but this document never seems to have made it past this draft stage.

25 See the judicial records (Urgichten) for the entirety of the second half of the 1580 s and the 1590 in StadtAA, RS. 
old calendar, some of Augsburg's Protestants demonstrated their commitment to commemorating the events of $1583 / 84$ by wearing white ribbons, something that between 1584 and 1586 had become a way to show loyalty to those who had fled Augsburg in the wake of the uprising of 1584 . These 'true hearts' represented their memory of the events as episodes in their confessionalised memory of the tumultuous years of the early 1580 s. Their continuing loyalty to and identification with those who had served as the ringleaders in the uprising of 4 June 1584 was as much a part of that confessionalised memory as was their continued observation of holidays according to the old calendar. This confessionalised memory animated a rather brisk cottage industry in penny pamphlets circulating throughout Augsburg and the Empire, which included songs of praise or sorrowful dirges for the sufferings of Müller and the Protestants in Augsburg. ${ }^{26}$ In contrast with the municipal memory of the uprising as a moment of civil disobedience and citizens' failure to respect imperially sanctioned and constitutionally prescribed authority, the events of the 158 os became for many of Augsburg's Protestants a basis on which to define themselves in marked difference to their Catholic neighbours. Though Augsburgers, both the leaders of the Protestant activist front and the municipal authorities, were able to lay formally to rest the debates over who had a right to name the ministers to serve in municipal churches and whether the calendar reform was to be implemented, there remained in the cultural landscape of Augsburg, for decades and, indeed, centuries, to come a difference in the way that many Protestants in Augsburg thought about the events of the early 1580 s.

Yet in the ability of Augsburgers to remain at peace while fostering such divergent memories of their own, common past, we can also see one reason why the city remained at peace despite all of the potential for conflict. What was effectively demonstrated was the degree to which diver-

${ }^{26}$ A collection of these songs can be found, transcribed, in SStBibAugsburg, $4^{\circ}$ cod. S 1, 'Collectanea zur Geschichte der Stadt Augsburg, 16. Jahrhundert'. It is very difficult to say with any certainty just how popular or widespread these songs were, but we can infer that they were popular enough from the fact that they were deemed worthy of careful transcription in this rather costly, fine volume. Alexander Fisher has discussed one of the most widely spread of the songs as reflected in the interrogation of its author, Abraham Schädlin (see his 'Song, Confession, and Criminality. Trial Records as Sources for Popular Music Culture in Early Modern Europe', Journal of Musicology 18, no. 4 (2001), 616-57). Allison Creasman, Censorship and civic order in Reformation Germany, 1517-1648. 'Printed poison \& evil talk' (Farnhamand Burlington, V.T.: Ashgate, 2012), esp. 147-184 has shown the lengths to which the municipal censors went in their efforts to stanch the flow of these texts in the civic spaces of the city's streets and marketplaces. 
gent memories could be accommodated even within the rigid structures of an early modern urban community. The memory of an event held among a particularistic confessional group was very much at odds with the official memory propagated by the political authorities. But that tension did not lead to open conflict. Instead, the one was relegated to the sphere of domestic sociability and private conscience and the other demanded public acquiescence. Though the official memory could not suffer the presence of a competing memory of the events in public spaces, it could not suppress the confessionalised memory cultivated at home. In Augsburg, the memories of these trying events thus mirrored a more general development that helped maintain peace in Augsburg in the years between the Peace of Augsburg and the coming of the Thirty Years War: politics, independent of confessional particularism, and a civic-mindedness centred on legal, social, and economic affairs were matters for public spaces and municipal business; confessional identity, matters of religion, as contemporaries put it, were restricted to the pews of churches and sermonhouses and to the privacy of citizens' homes. 